\title{
Temporo-mandibular joint disease in ankylosing spondylitis
}

\author{
C. DAVIDSON, J. A. WOJTULEWSKI, P. A. BACON*, AND D. WINSTOCK \\ From the Departments of Rheumatology at St. Bartholomew's Hospital and the Westminster Hospital, \\ London
}

\begin{abstract}
Davidson, C., Wojtulewski, J. A., Bacon, P. A., and Winstock, D. (1975). Annals of the Rheumatic Diseases, 34, 87. Temporo-mandibular joint disease in ankylosing spondylitis. The occurrence of temporo-mandibular joint (TMJ) disease in ankylosing spondylitis is not widely recognized and its incidence is disputed. Seventy-nine patients attending two routine rheumatology clinics were therefore examined by a dental surgeon and nine $(11.5 \%)$ were considered to have specific TMJ involvement. These patients were older than the remainder, and had more extensive spinal and peripheral joint disease. Symptoms were mild and the predominant clinical feature was restricted mouth opening, which could present considerable difficulties during emergency anaesthesia. Bilateral condylectomy was undertaken in one patient with some benefit.
\end{abstract}

Arthritis of the TMJ is commonly found in rheumatoid arthritis (Franks, 1969), and has also been described in Still's disease (Still, 1897) and psoriatic arthropathy (Lundberg and Ericson, 1967), but that it may occur in patients with ankylosing spondylitis is less well recognized. Severe TMJ involvement was in fact present in Marie's original case (Leri, 1899), but since then there have been only sporadic reports of its occurrence (Thoma, Howe, and Wenig, 1945; Mériel, Ruffié, Cadenat, Fournié, and Blanc, 1960; Boering, 1966; Bruszt, 1967; Marbach, 1969) and even in larger surveys little clinical information is given.

This study was prompted by a patient with severe TMJ involvement and reports a clinical and radiological survey among patients with ankylosing spondylitis attending St. Bartholomew's and the Westminster Hospitals.

\section{Patients and methods}

\section{PATIENT SELECTION}

Seventy-nine patients (67 male, 12 female) who were routinely attending the rheumatology clinics, took part in the study. All patients fulfilled the New York Criteria for the diagnosis of definite ankylosing spondylitis (Bennett and Burch, 1967).

\section{CLINICAL ASSESSMENT}

Each patient was questioned as to the duration and mode of onset of symptoms, and for the presence of peripheral joint or systemic involvement. The range of spinal mobility was measured by spondylometry, and on the basis of previous observations (Sturrock, Wojtulewski, and Hart, 1973) the patients were divided into three grades: grade I normal; grade II $50-100 \%$ normal; grade III $0-50 \%$ normal. The extent of spinal deformity was assessed by the distance from the occiput to the vertical when measured against a wall. Chest expansion was measured at the level of the lower sternal margin, peripheral joint involvement was noted, and the cardiovascular system checked by clinical examination and ECG.

\section{TMJ INVOLVEMENT}

Each patient was questioned and examined in a dental clinic by one observer (D.W.). The TMJ was palpated for tenderness and crepitus, any restriction of jaw opening or asymmetry of condylar function noted, and the maximum inter-incisal distance measured (the lower limit of normal being $35 \mathrm{~mm}$ ). In addition, a full dental examination was made to exclude other causes of TMJ dysfunction such as malocclusion. Patients with abnormal signs or symptoms were $x$-rayed using both standard open/closed views of the joint and an orthopantomograph.

\section{Results}

CLINICAL DATA

The clinical features of the 79 patients studied are indicated in Table I. The onset of the disease had been acute, with or without polyarthritis, in 31 patients $(39 \%)$ and the mean duration was 16.7 years. Twenty-seven patients $(34 \%)$ had suffered from iritis, and peripheral joint involvement was present in $33(42 \%)$. Only two patients, both male, had 
Table I Comparison of the clinical features of patients with and without TMJ disease, indicating mean and $\stackrel{\Phi}{\Phi}$ range

\begin{tabular}{|c|c|c|c|c|c|c|c|c|c|c|c|c|}
\hline & \multirow[b]{2}{*}{$\begin{array}{l}\text { No. of } \\
\text { patients }\end{array}$} & \multirow[b]{2}{*}{$\begin{array}{c}\text { Age } \\
s(y r s)\end{array}$} & \multirow[b]{2}{*}{$\begin{array}{l}\text { Duration } \\
(y r s)\end{array}$} & \multicolumn{2}{|c|}{ Mode of onset } & \multirow{2}{*}{$\begin{array}{l}\text { Peri- } \\
\text { pheral } \\
\text { joint } \\
\text { involve- } \\
\text { ment }\end{array}$} & \multicolumn{3}{|c|}{$\begin{array}{l}\text { Spinal } \\
\text { movement* }\end{array}$} & \multirow{2}{*}{$\begin{array}{l}\text { Chest } \\
\text { expansion } \\
(\mathrm{cm})\end{array}$} & \multirow{2}{*}{$\begin{array}{l}\text { Skull to } \\
\text { wall } \\
(\mathrm{cm})\end{array}$} & \multirow{2}{*}{$\begin{array}{l}\text { Inter- } \\
\text { incisal } \\
\text { distance } \\
(\mathrm{mm})\end{array}$} \\
\hline & & & & Acute & $\begin{array}{l}\text { Insidi- } \\
\text { ous }\end{array}$ & & $I$ & $I I$ & III & & & \\
\hline TMJ normal & 63 & $\begin{array}{l}42 \cdot 4 \\
(19-78)\end{array}$ & $\begin{array}{l}15 \cdot 5 \\
(0 \cdot 2-33)\end{array}$ & 27 & 36 & 24 & 18 & 29 & 16 & $\begin{array}{l}3 \cdot 6 \\
(0 \cdot 2-9 \cdot 5)\end{array}$ & $\begin{array}{l}3 \cdot 7 \\
(0-30)\end{array}$ & $\begin{array}{l}42 \cdot 5 \\
(35-60)\end{array}$ \\
\hline \multicolumn{13}{|c|}{ TMJ abnormal } \\
\hline A & 9 & $\begin{array}{l}47 \cdot 2 \\
(32-73)\end{array}$ & $\begin{array}{l}22 \cdot 5 \\
(6-31)\end{array}$ & 2 & 7 & 5 & 2 & 1 & 6 & $\begin{array}{l}3 \cdot 1 \\
(0-10)\end{array}$ & $\begin{array}{l}8 \cdot 3 \\
(0-30)\end{array}$ & $\begin{array}{l}23 \cdot 7 \\
(12-33)\end{array}$ \\
\hline B & & $\begin{array}{l}54 \cdot 0 \\
(44-68)\end{array}$ & $\begin{array}{l}23 \cdot 1 \\
(15-30)\end{array}$ & 0 & 3 & 1 & 0 & 1 & 2 & $\begin{array}{l}2 \cdot 1 \\
(1 \cdot 5-2 \cdot 5)\end{array}$ & $\begin{array}{l}11 \cdot 8 \\
(10-14)\end{array}$ & $\begin{array}{l}27 \cdot 6 \\
(23-32)\end{array}$ \\
\hline $\mathrm{C}$ & 4 & $\begin{array}{l}42 \cdot 0 \\
(23-57)\end{array}$ & $\begin{array}{l}20 \cdot 5 \\
(2-30)\end{array}$ & 2 & 2 & 3 & 0 & 2 & 2 & $\begin{array}{l}5 \cdot 6 \\
(3-11)\end{array}$ & $\begin{array}{l}5 \cdot 5 \\
(0-15)\end{array}$ & $\begin{array}{l}39 \cdot 2 \\
(37-40)\end{array}$ \\
\hline
\end{tabular}

evidence of cardiovascular disease, both with aortic incompetence.

\section{TMJ EXAMINATION}

TMJ symptons were only volunteered by one patient in the study, but in those with abnormal signs, some symptoms were usually found on direct questioning. Sixteen patients $(20.5 \%)$, fourteen male two female, were found to have clinical evidence of TMJ disease on the basis of their symptoms and signs, and these patients may be considered in three groups.

(A) Nine patients ( 8 male, 1 female) had restricted mouth opening without any other apparent cause. Pain and/or limitation of movement had been noted by six of them for between 1 and 20 years and in seven there was definite tenderness of one or both joints. Radiological changes were present in four patients, three of whom had severe restriction of movement (inter-incisal distance 12-15 mm). These changes included flattening or erosion of the condylar heads (Fig. 1) and asymmetry or restricted movement when assessed by open/closed views on the orthopantomograph (Fig. 2).

(B) Three subjects ( 2 male, 1 female) were found to have malocclusion and restricted mouth opening; two patients had an overbite of the upper teeth on the lower, and the other a retruding lower jaw. Radiological examination of the TMJ was negative and all were symptom free.

(C) Four subjects, all male, had pain and clicking of the TMJ and were found to have tenderness over one or both joints. Mouth opening was painful but within the normal range, and radiological examination was normal.

It was concluded from the clinical features and examination of these patients that while arthritis of the TMJ could be present in any or all of them, those in group A were most likely to have specific involvement. In group B malocclusion could account for the joint abnormality, and those in group $\mathrm{C}$ were응 thought to have the 'pain dysfunction' syndrome(Schwartz, 1959), which is very common in the general T population (Franks 1964).

CORRELATION OF CLINICAL FEATURES WITH TMJ DISEASE

A comparison of the clinical features of the thrâ groups of patients with TMJ disease and those without is seen in Table I. Those with TMJ abno of malities had had the disease longer, and it had much more often begun insidiously. Spinal involvement, as assessed both by spondylometry and the degree of $\frac{\mathrm{O}}{\mathrm{O}}$ deformity present, was more extensive in those with $\cong$ TMJ disease. Marked neck flexion (skull to wall $\overrightarrow{\overrightarrow{0}}$ distance $10 \mathrm{~cm}$ or greater) was found in seven patients with TMJ disease and it is possible that in these patients jaw opening was to some extent

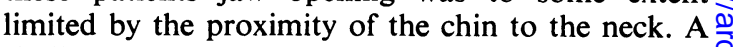
similar degree of neck flexion was, however, present in eleven of the remaining 63 patients $(17.5 \%)$ and 3 Fig. 3 shows two patients with equal neck deformity, one with normal, and the other grossly abnormal, 3 jaw opening. Patients with TMJ involvement had evidence of peripheral joint disease more often $(55 \%)$ than in the remaining patients $(38 \%)$, and in $\frac{7}{0}$ three of the four with severe TMJ involvement there was widespread disease elsewhere. There were no $N$ significant differences in haemoglobin and ESR $\mathrm{N}$ between the groups with and without TMJ disease.

\section{HISTOLOGICAL FINDINGS}

In one patient restricted jaw opening became in- 6 creasingly troublesome and a bilateral condy- $\mathbb{D}$ lectomy was therefore undertaken. At operation, both capsules were intact but the menisci were damaged and the condylar surface eroded as sug- $\overrightarrow{\mathbb{D}}$ gested by the $x$-ray (Fig. 1). The microscopical appearance suggested an inflammatory arthritis, 

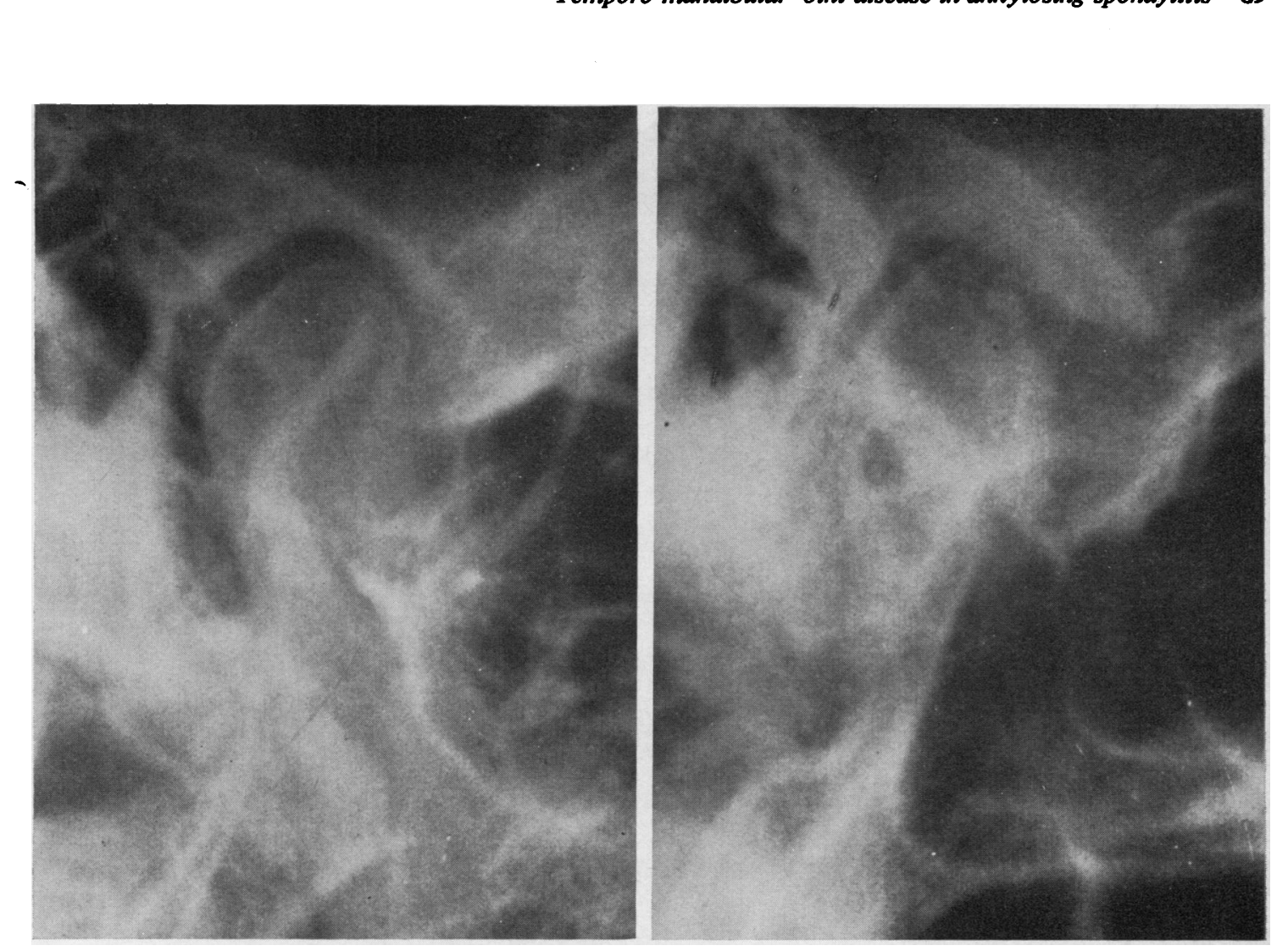

FIG. 1 Standard $\mathrm{x}$-rays showing closed views of the temporo-mandibular joint. Left: normal; Right: erosive changes in the mandibular condyle

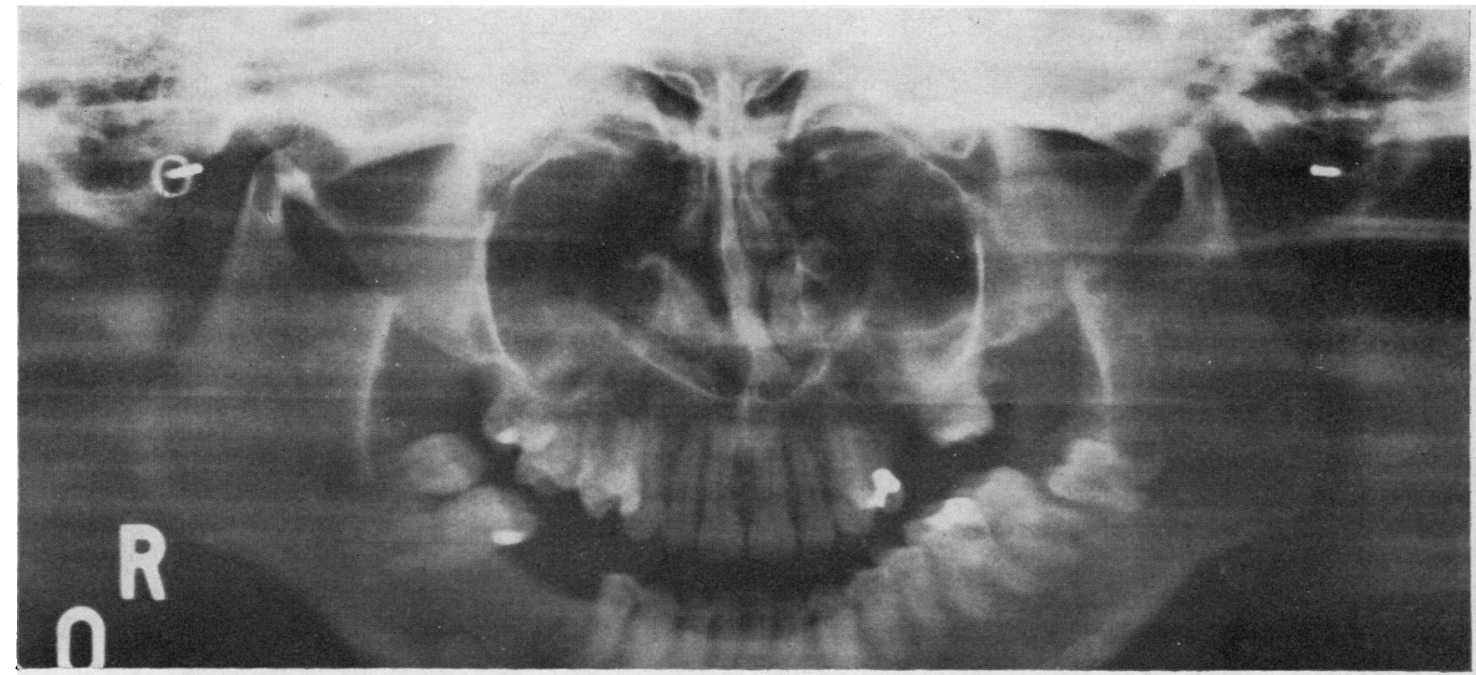

FIG. 2 Orthopantomograph of the jaws showing restricted opening in a patient with temporo-mandibular joint involvement 

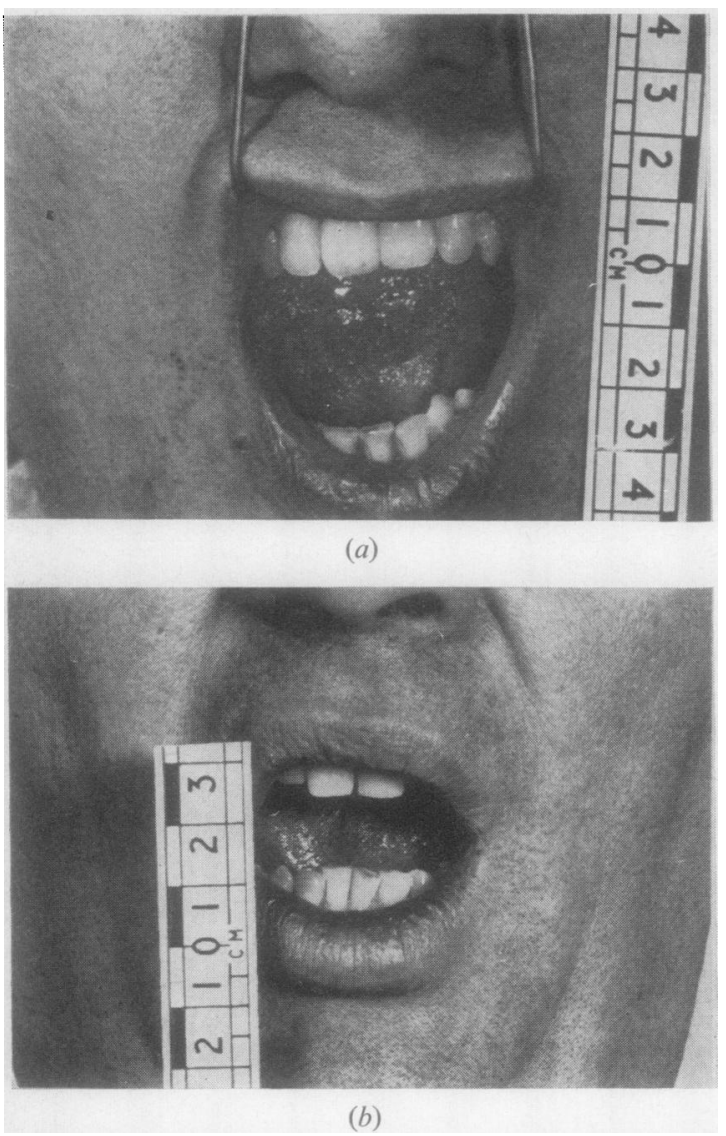

FIG. 3 Mouth opening in two patients with pronounced flexion deformities of the neck. (a) Normal; (b) restricted opening

although considerable damage had occurred to the specimen during surgical removal. The sections were examined by Dr. J. Ball (Department of Rheumatology, University of Manchester), who reported as follows: "There is pannus on the cartilaginous surface at the articular margin. Here the subchrondral marrow spaces contain granulation tissue in which numerous plasma cells can be seen. The small fragment of attached synovium is hyperplastic but contains only scanty inflammatory cells. At the attachment of the capsule to the bone there are cellular zones reminiscent of those sometimes seen in ankylosing spondylitis. The findings indicate mild erosive arthritis. The presence of cysts beneath degenerate articular cartilage indicates that degenerative joint disease is also present'.

There were no operative complications and the patient had a good symptomatic improvement with relief of pain, despite only moderate improvement in jaw opening (inter-incisal distance $24 \mathrm{~mm}$ ).

\section{Discussion}

INCIDENCE

It is clear from this study that only a minority of $\frac{\square}{\omega}$ patients with ankylosing spondylitis develop TMJ involvement and this is in broad agreement with $\stackrel{9}{+}$ previous surveys, as indicated in Table II. The exact incidence of TMJ involvement may, however, be difficult to determine in the absence of specific clinical features. Thus, in the present study all sixteen patients with pain and/or limitation of $\approx$ movement of the TMJ might have had specific involvement, but seven had other abnormalities which could account for the findings. The clinical diagnosis was substantiated by histological findings in one patient and as far as we are aware this had only been reported once previously (Thoma and others, 1945) where the changes were nonspecific. In previous surveys no clinical details of the TMJ involvement were given, and these diagnostic difficulties may account for the variation between surveys commented on by Maes and Dihlman (1968).

Table II Incidence of temporo-mandibular joint involvement in ankylosing spondylitis

\begin{tabular}{|c|c|c|}
\hline & $\begin{array}{l}\text { No. of } \\
\text { patients }\end{array}$ & $\begin{array}{l}\% T M J \\
\text { involvemext }\end{array}$ \\
\hline \multicolumn{3}{|c|}{$\begin{array}{l}\text { Forestier, Jacqueline, and } \\
\text { Rotes-Querol }\end{array}$} \\
\hline Einaudi and Viara & & \\
\hline $\begin{array}{l}\text { (1964) } \\
\text { Maes and Dihlman }\end{array}$ & 65 & 8 \\
\hline (1968) & 100 & 4 \\
\hline
\end{tabular}

\section{CLINICAL FINDINGS}

Involvement of the TMJ in ankylosing spondylitis appears to give rise to few serious symptoms until gross restriction of jaw movement has occurred. This constrasts with the acute pain and tenderness occurring in rheumatoid arthritis, which usually resolves spontaneously, and only rarely gives rise 오 to permanent restriction of jaw opening (Mayne and $>$ Hatch, 1969). The insidious onset with slow but progressive limitation of movement in ankylosing $N$ spondylitis is in keeping with the general nature of joint involvement in the disease. Patients with $\mathbb{O}$ TMJ involvement had, as might be expected, evidence $N_{\omega}$ of more extensive spinal disease and peripheral joint involvement than the remaining patients. Theo

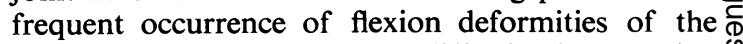
neck may give rise to some difficulty in assessing $\stackrel{?}{+}$ TMJ function due to approximation of the chin to 7 the chest, and it is interesting that marked neck웅 flexion was present in three previous case reports (Leri, 1899; Boering, 1966; Bruszt, 1967). 


\section{RADIOLOGICAL CHANGES}

Radiological changes were only found in four of the sixteen patients with TMJ signs. Radiological examination of the TMJ is often unreliable in showing specific abnormalities, even when a number of different views are taken. This is improved by the orthopantomograph in which both joints may be compared directly and any asymmetry of opening shown (Smith and Sowray, 1968). Even by this technique no abnormality was found except in patients with gross restriction in movement. This is in contrast to the frequent erosions found in rheumatoid arthritis (Franks, 1969) and suggests that in ankylosing spondylitis radiological changes in the TMJ occur at a relatively late stage.

\section{Conclusions}

In his review of ankylosing spondylitis in 1899 Leri commented, 'We have now come to understand why authors are silent on ankylosis of the temporomandibular joint; it is the difficulty in recognizing it unless it is expressly looked for, and, unless it becomes, severe adequate movement can still take place.' TMJ involvement does not appear to be as common as Leri suggested, but it is important that it should be recognized since it can present an additional hazard to patients with ankylosing spondylitis during general anaesthesia and dental emergencies. Clinically restricted jaw movement can easily be recognized, an inter-incisal distance of less than 3 finger breadths (approximately $40 \mathrm{~mm}$ ) being abnormal. Although restricted jaw opening may occur in other conditions as a reflex response to pain in the joint, clinical evidence of muscle spasm is usually present and may be overcome, for example during a short anaesthetic. Where severely limited jaw opening is present, considerable improvement may be expected after condylectomy (Thoma, 1969).

We would like to thank Drs. H. W. Balme and F. D. Hart for permission to study patients under their care; Dr. J. Ball for his report on the histological findings; Dr. R. Sturrock for help with patient assessment; and Mrs. K. Dunkley for secretarial assistance.

\section{References}

BenNeTt, P. H., AND Burch, T. A. (1967) Bull. rheum. Dis., 17, 453 (New York Symposium on population studies in rheumatic diseases: new diagnostic criteria)

BoERING, G. (1966) in 'Arthrosis Deformans van het Kaakgewricht', p. 228. Tholen, Utrecht

BRUSZT, P. (1967) Oral Surg., 23, 443 (Greatly impeded mouth opening in Bechterew's disease)

EINAUdI, G., AND ViaRA, M. (1964) Reumatismo, 16, 351 (Richerche sul comportamento dell'articolazione temporo-mandibolare nei paziente affetti da spondilite anchilosante)

Forestier, J., JaCQueline, F., AND Rotes-Querol, J. (1956) in 'Ankylosing Spondylitis', p. 154. Mosby, St. Louis

Franks, A. S. T. (1964) Dent. Practit., 15, 94 (The social character of temporomandibular joint dysfunction) (1969) Ann. rheum. Dis., 28, 139 (Temporo-mandibular joint in adult rheumatoid arthritis)

LERI, A. (1899) Rev. Méd. (Paris), 19, 801 (La spondylose rhizomélique)

LUNDBERG, M., AND ERICSON, S. (1967) Acta derm-venereol. (Stockh.), 47, 354 (Changes of the temporomandibular joint in psoriasis arthopathica)

Maes, H. J., AND Dihlman, W. (1968) Fortschs. Rontgenstr., 109, 513 (Befall der temporomandibulargelenke bei der Spondylitis ankylopoetica)

MARBACH, J. J. (1969) Dent. Radiograph Photog., 42, 51 (Arthritis of the temporomandibular joint)

MaYNE, J. G., AND HATCH, G. S. (1969) J. Amer. dent. Ass., 79, 125 (Arthritis of the temporomandibular joint)

Mériel, P., Ruffié, R., CAdenat, J., FourniÉ, A., AND Blanc, P. (1960) J. Radiol. Electrol., 41, 105 (Exploration radioclinique de l'articulation temporo-maxillaire)

SchWARTZ, L. (1959) in 'Disorders of the Temporomandibular Joint.' Saunders, Philadelphia and London

SMITH, N. J. D., AND SowraY, J. H. (1968) Brit. J. Radiol., 41, 871 (The use of the orthopantomograph)

StILL, G. F. (1897) Med-Chir. Trans., 80, 47 (On a form of chronic joint disease in children)

StURRock, R. D., WoJTulewski, J. A., AND HART, F. D. (1973) Rheumatol. Rehab., 12, 135 (Spondylometry in a normal population and in ankylosing spondylitis)

Thома, K. H. (1969) in 'Oral Surgery', 5th ed., p. 659. Mosby, St. Louis

—, Howe, H. D., AND WeNIG, M. (1945) Amer. J. Orthodont., 31, 244 (Ankylosis of the jaw) 